cells, has been tried in our group to minimize the problem of hypoplasia and drug toxicity. The regimen using cytosine arabinoside and 6 thioguanine (Table I) was chosen after personal communications from Dr. Crowther and Dr. E. Freireich (M.D.

TABLE I

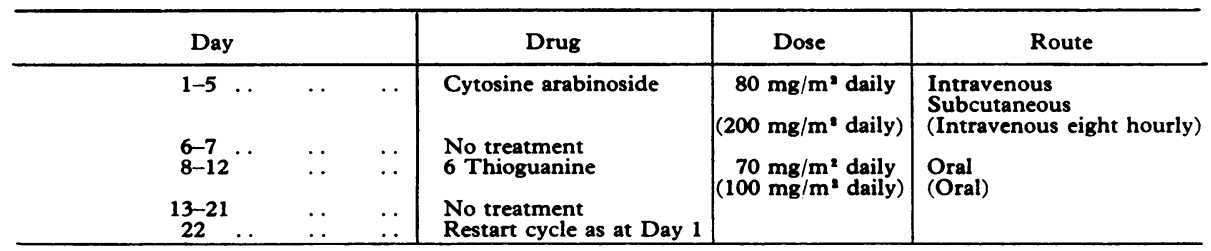

Anderson Hospital, Houston, Texas), who has used a similar programme in the past. This represents an attempt to synchronize the blast cell cycle. Inhibition of DNA synthesis by the cytosine arabinoside leads to partial bone marrow hypoplasia, with a "rebound" of activity following the withdrawal of this drug. Crowther and Freireich suggested that the maximal rebound activity

lymphoblastic leukaemia; if treatment is started with combination chemotherapy of three or four drugs the morbidity is severe, even leading to mortality, whereas the use of two agents only (prednisolone and vincristine) is associated with virtually no toxic side effects. After remission is achieved increased numbers and doses of drugs can be given more safely, and we feel

TABLE II

\begin{tabular}{|c|c|c|c|c|c|c|}
\hline \multirow{2}{*}{ Case } & \multirow{2}{*}{$\begin{array}{c}\text { Age } \\
\text { (Years) }\end{array}$} & \multirow{2}{*}{ Diagnosis } & \multicolumn{2}{|c|}{ Pretreatment } & \multirow{2}{*}{ Result } & \multirow{2}{*}{$\begin{array}{l}\text { Length of } \\
\text { Remission }\end{array}$} \\
\hline & & & $\begin{array}{l}\text { Platelet } \\
\text { per } \mathrm{mm}^{3}\end{array}$ & $\begin{array}{c}\text { Blasts } \\
\text { per } \mathrm{mm}^{3}\end{array}$ & & \\
\hline $\begin{array}{l}1 \\
2 \\
3 \\
4 \\
5 \\
6 \\
\end{array}$ & $\begin{array}{l}12 \\
23 \\
20 \\
50 \\
19 \\
31 \\
\end{array}$ & $\begin{array}{c}\text { Acute myeloblastic leukaemia } \\
\text { Stem cell leukaemia } \\
\text { Acute myeloblastic leukaemia } \\
\text { Acute myeloblastic leukaemia } \\
\text { Stem cell leukaemia } \\
\text { Acute myeloblastic leukaemia }\end{array}$ & $\begin{array}{r}5,000 \\
5,000 \\
18,000 \\
<10,000 \\
50,000 \\
13,000 \\
\end{array}$ & $\begin{array}{r}10,000 \\
40,000 \\
80,000 \\
6,000 \\
38,000 \\
\end{array}$ & $\begin{array}{l}\text { CR } \\
\text { CR } \\
\text { F } \\
\text { CR } \\
\text { CR } \\
\text { CR } \\
\end{array}$ & $\begin{array}{l}7+\text { months } \\
3 \text { months } \\
4+\text { months } \\
3+\text { months } \\
5+\text { months }\end{array}$ \\
\hline
\end{tabular}

$\mathrm{CR}=$ complete remission. $\mathrm{F}=$ failed.

occurs between 24 hours and 72 hours. 6 thioguanine was therefore administered after a gap of 48 hours for 5 days, when it was thought there would be augmented uptake due to increased DNA synthesis.

When remission is achieved the marrow is capable of withstanding larger doses of both these drugs. In our cases the doses were increased to the higher level in four of six patients when in complete remission. A fifth patient achieved a partial remission on the smaller dose and went into complete remission when the dose was increased to the higher levels.

The results are shown in Table II. Six patients with acute myeloblastic leukaemia or stem cell leukaemia have so far been studied. All the patients had received previous antileukaemia therapy or had to be excluded from the current Medical Research Council protocol for other reasons. Of the six patients, five achieved a complete remission and one showed no response. One patient relapsed after three months; the others are still in remission, the longest seven months. These encouraging recults were achieved with minimal side effects attributable to drug toxicity and no evidence of marrow aplasia. Platelet counts started to return to normal between 20 and 38 daysthat is, after two or three courses. The treatments were continued after remission. The maximum number of courses so far achieved is six. It is intended to carry on with these treatments while remission lasts. In one case the treatment had to be changed after five courses because of drug intolerance; she was in remission at the time and remains so now. that this approach to therapy offers many advantages over previous regimens, with much less morbidity and higher remission rates.-We are, etc.,

R. J. GUYER

D. A. WINFIELD

R. T. Shahani

Department of Haematology,

E. K. BLACKBURN Children's Hospital
Sheffield, Yorks

\section{Labelled Fibrinogen in Renal} Transplantation

SIR,-I would like to reply to the letter of Dr. P. W. Straub (19 December, p. 746), in which he makes certain remarks about the use of radioactive fibrinogen for diagnosing rejection in renal transplants during the early postoperative period (30 May, p. 517)

He found elevated levels of radioactivity over the transplants of two patients in whom there were no other signs of rejection. In one of the patients postoperative bleeding could well have produced the anomalous result. The labelled fibrinogen was given on the second post-transplant day, which is earlier than I would suggest since a certain amount of "oozing" of blood and lymoh is to be expected at this time. This would have resulted in a local extrarenal collection of labelled fibrin, which would have caused an increase in the radioactivity of that area. The second patient showed a positive response to the test some 16 days after transplantation, when postoperative bleeding was evidently not the cause. Dr. Straub has attributed this result to "wound healing" and he may be right. One point to note, however, is that the transplant radioactivity exceeded that of the heart $(>120 \%)$ only on the sixth day of the test. It is my experience that when rejection is occurring the increased transplant activity becomes evident much earlier, usually within 2-3 days of the time the fibrinogen was injected. All the same a late rise as found by Dr. Straub may not always be a "false-positive," as the accompanying Figure shows.

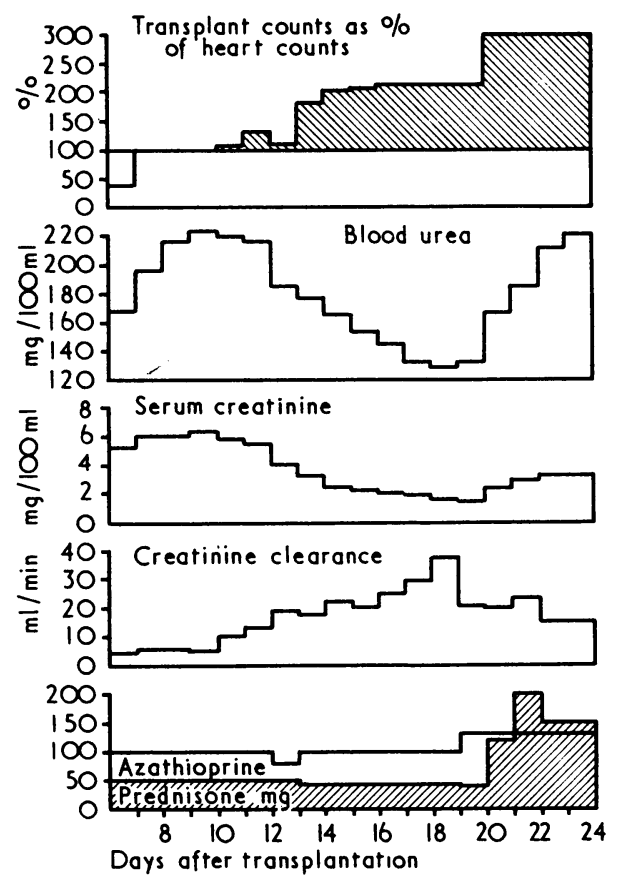

Male 14 years. Cadaveric renal transplant. 125I-Fibrinogen was given on the seventh posttransplant day, when renal function was depressed as a result of ischaemic tubular necrosis. An increase in the percentage radioactivity of the transplant occurred a week before any other signs of rejection.

This patient, who received a cadaveric renal transplant, was given labelled fibrinogen on the seventh post-transplant day, when the effects of ischaemic tubular necrosis were still evident. Renal function improved one week later, but at this time the percentage radioactivity of the transplant began to increase. Unfortunately, he was not treated for rejection at this time and week elapsed before rejection was evident clinically and appropriate action was taken. This episode was not reversed and the rejected kidney was removed two weeks afterwards.

I accept that occasional false-positives will occur with this technique, as they will with any investigative procedures, but on the whole it has proved reliable in my hands and I believe it to have a definite place in the management of renal transplant patients during the early anuric period.-I am, etc.,

JoHN R. SALAMaN University Hospital of Wales,

\section{Simple Guide to Prognosis in Hypertension}

SIR,-In your leading article (19 December, p. 697) on prognosis in hypertension, you highlight a common practical problem in clinical medicine-namely, how 